This is an Accepted Manuscript of an article published by Taylor \& Francis in Journal of International Trade \& Economic Development on 19/11/19, available online: https://www.tandfonline.com/doi/ full/10.1080/09638199.2019.1692895 


\title{
Measuring the volatility spill-over effects of crude oil prices on the exchange rate and stock market in Ghana
}

Mutawakil M. Zankawah and Chris Stewart ${ }^{\star}$

Department of Economics, Kingston University London

\begin{abstract}
This paper examines shock and volatility spill-over effects from crude oil prices to Ghana's exchange rate and stock market. We employ multivariate GARCH BEKK and TBEKK models using monthly data from January 1991 to December 2015. We address two main issues. First, whether oil price movements affect Ghana's exchange rate and stock market. There are very few previous papers that consider the impact of such volatility spill-overs for Ghana and we are the first to do so in a four-variable system of equations. Second, whether any oil price effects depend on the treatment of oil prices as exogenous or endogenous. We are the first to consider specifications that treat crude oil prices spill-over effects as exogenous. We find that oil prices have significant spill-over effects on the exchange rate. This result is unaffected by the treatment of oil prices as exogenous or endogenous. However, the relationship between oil prices and Ghana's stock market depends on whether the oil price is exogenous or endogenous. The implication of these results is that internationally diversified portfolio investors in Ghana should use hedging strategies such as currency forwards, futures, and options to protect their investments from exchange rate risk emanating from oil price shocks.
\end{abstract}

Keywords: Ghana, exchange rate and stock markets, oil prices, exogeneity, shock and volatility spill-overs, system GARCH-TBEKK model.

JEL classification: C32, F31, F41.

* Corresponding author: Chris Stewart, Department of Economics, School of Law, Social and Behavioural Sciences, Kingston University, Penrhyn Road, Kingstonupon-Thames, Surrey, KT1 2EE, UK. e-mail: c.stewart@kingston.ac.uk; Orchid page: http://orcid.org/0000-0001-7893-1364. 


\section{Introduction}

Our aim is to investigate the shock and volatility spill-over effects of world crude oil prices on the Ghanaian exchange rate and stock market. This topic is important because of the financialization of the oil market in recent years (Antonakakis et al 2017). According to some researchers, the financialization of the oil market is due to increased hedging and speculative activities by investors (Hamilton and Wu 2014, Alquist and Kilian 2010, and Buyukashin et al 2010). The relationships between oil prices and exchange rates, and oil prices and stock markets have been examined by Gosh (2011), Lizardo and Mollick (2011), Amano and Norden (2008), Masih et al (2011), Basher and Sadorsky (2006), Chen (2010), and Filis (2010). However, no previous study has investigated such effects with oil prices treated as exogenous for a small country. For small countries like Ghana, the treatment of world oil prices as endogenous can be a problem since economic activities in those countries will unlikely have any significant effect on world oil prices (compared to economic activities in developed countries). However, world oil prices can influence economic activities in those countries. Hence, treating world oil price as endogenous for those countries could lead to model misspecification, or results that are theoretically unjustifiable.

Also, despite the existence of a large body of literature investigating the link between oil prices, macroeconomic variables, and the financial sector for both developed countries and developing countries, there has been little research for the sub-Saharan African countries such as Ghana. Ghana is particularly interesting because of the country's high dependence on oil for energy, and its continuous dependence on the importation of petroleum products despite becoming an oil producer. The significance of oil to the Ghanaian economy is discussed in detail in section 2. Hence, this paper seeks to address two research questions: firstly; does the volatility of world oil prices 
influence the volatility of the Ghana stock market index and the Ghana cedi exchange rate? Second; are the effects of world oil prices on the Ghanaian currency exchange rate and the Ghana stock market related to the treatment of world crude oil prices as exogenous or endogenous?

The traditional view argues that oil prices affect exchange rates through the terms of trade effect (Chen and Chen 2007). A rise in oil prices reduces the demand for the domestic currency of an oil-importing country, hence driving down the value of the currency. Traditional finance theory also posits that oil prices can affect stock prices directly by impacting future cash flows or indirectly through an impact on the discount rate used to discount future cash flows (Basher and Sadorsky, 2006 and Muhtaseb and Al-Assaf, 2017). This assumes that oil price increases will raise the cost of production and the cost of doing business, which reduce profits and share prices. These theories, together with the findings of the previous papers mentioned above underline the importance of this study.

To address the research questions stated above, this study shall employ the multivariate $\mathrm{GARCH}-\mathrm{BEKK}$ and the triangular $\mathrm{BEKK}$ models to evaluate the shock and volatility spillover effects of oil prices on the Ghana currency exchange rate and the Ghana stock market. World oil prices are treated as endogenous in the BEKK model whilst in the triangular BEKK model, they are treated as exogenous. Hence, the treatment of crude oil prices as exogenous to study such effects in a small country like Ghana represents a contribution of this paper.

The paper is organised as follows. Section 2 discusses the significance of oil Ghana's economy and oil while section 3 provides a literature review. Section 4 discusses the 
data with some preliminary analysis. Section 5 presents the methods and Section 6 discusses the results. Section 7 concludes the paper.

\section{Ghana's economy and oil}

Ghana's dependence on oil has been rising for several years. Oil accounted for $28 \%$ of Ghana's total energy consumption in 2000 , and this substantially increased to $52 \%$ in 2014 (Energy Commission of Ghana, 2015). Further, important sectors such as transport, agriculture, and to some extent industry (manufacturing and mining) depend solely on oil. Petroleum products account for $100 \%$ of the energy used by the transport and agricultural sectors (Energy Commission of Ghana, 2015). Between 2004 and 2014, Ghana's oil consumption increased by about $54 \%$ - oil consumption increased from 45 barrels a day in 2004 to 83 barrels a day in 2014 (Indexmundi). Despite becoming an oil producer in 2011, significant amounts of petroleum products consumed in Ghana are still imported, and the quantities of refined petroleum products imported continue to rise - petroleum product imports increased from 1,589.9 kilo tonnes in 2010 to 3,393.8 kilo tonnes in 2014 (Energy Commission of Ghana, 2015).

Given the high importance of oil and petroleum product imports to the Ghanaian economy, the price of oil could influence financial markets, such as the stock market and especially the exchange rate, in Ghana. Since Ghana adopted a flexible exchange rate $^{1}$ in the mid-1980s, the Ghanaian currency subsequently witnessed remarkable

\footnotetext{
1 In 1982 the bilateral exchange rate of the Ghanaian currency against the US dollar was $\not 2.75$ per US $\$ 1$. Ghana agreed to reform its exchange rate policy, to implement a flexible exchange rate regime and devalue the local currency. By 1996 the cedi declined to $\not 1754$ per US $\$ 1$. The cedi continued to depreciate at an alarming rate for the rest of the 1990s. By December 2000 the cedi suffered its highest annual depreciation, exchanging at $\not 7047$ per US $\$ 1$, representing a depreciation of $99 \%$ from the previous year. In 2007 the government redenominated the currency and a new currency called the Ghana cedi $(\mathrm{GH} \not)$ replaced the old currency. The new currency was trading at $\mathrm{GH} \not 0.9704$ per US $\$ 1$ at the time of the redenomination. However, the new Ghana cedi fell steadily against the US dollar and by 2015 the exchange rate was about $\mathrm{GH} \notin 3.795$ per US $\$ 1$.
} 
depreciation and volatility. The government has attempted, without success, to manage a stable exchange rate. This is largely due to balance of trade deficits because of a continuous rise in imports, which oil is part of. The value of Ghana's oil imports increased from US $\$ 0.511$ billion in 2002 to US $\$ 3.693$ billion in 2014 (Bank of Ghana statistical bulletin, 2015). In 2014, the import of oil products constituted $33.8 \%$ of total imports.

As is well known, the price of imported commodities can affect movements in the domestic currency. Considering the volume of Ghana's oil imports, and the volatility in oil prices over the last few decades, the Ghanaian currency could be susceptible to oil price changes. Since the US dollar is the main invoicing and settlement currency in the world oil market, Ghanaian oil importers must sell their domestic currency (the Ghana cedi) in the foreign exchange market in order to obtain liquidity in US dollars to pay for their oil imports. As a result, movements in oil prices can have a destabilizing effect on the local currency.

The price of oil and petroleum products could also be important determinants of movements of the Ghana stock market. Three possible reasons why oil prices and Ghana's stock market could be related are as follows. First, the mining and manufacturing industries (which rely heavily on oil) constitute the second largest industries in terms of the number of listed companies on the Ghana stock market. Second, there are oil companies listed on the Ghana stock market, such as, Tullow Oil, Total Petroleum Ghana, and Ghana Oil, and some of these companies are foreign owned. As a result, oil price movements can have a direct effect on their share prices which may have some impact on the Ghana stock exchange index. Third, as oil plays an important role in Ghana's production activities, oil price movements are expected to impact Ghana's stock market if oil prices affect macroeconomic variables such as 
output and inflation. Inflationary pressures and economic downturns deteriorate consumer sentiment and slow down overall consumption and investment spending which can affect the stock market.

\section{Literature review}

Hamilton (1983) first explored the relationship between oil prices and macroeconomic variables when he examined the role of oil price shocks on US business cycles. Subsequent research has expanded to include the link between oil prices and other macroeconomic variables and the financial sector. In the last two decades there has been considerable research on the effects of oil price shocks on exchange rates and stock markets.

The nature of oil price effects on exchange rates remains inconclusive. Beckmann and Czudaj (2013), Ghosh (2010), Dogan et al (2012), Selmi et al (2012), Chen and Chen (2007), Lizardo and Mollick (2010) and Kin and Courage (2014) suggest that oil price increases depreciate exchange rates. However, Amano and Norden (1998) and Benassy-Quere et al (2007) demonstrate that oil price increases lead to an exchange rate appreciation.

Other studies distinguish between oil-exporting and oil-importing countries to assess whether the crude oil price effects on their currencies differ. Aziz and Bakar (2011) found that real oil price increases lead to a depreciation of oil-importing countries' exchange rates, whilst oil prices and exchange rates of oil-exporting countries have no relationship. In contrast, Yang et al (2017) found that the degree of interdependence between oil prices and exchange rates is greater for oil-exporting countries than for oil-importing countries. Similarly, Reboredo (2012) suggests that the co-movement between oil prices and exchange rates is more intense for oil-exporting 
countries and less intense for oil-importing countries. While Jiang and Gu (2016) find that the oil price-exchange rate relationship is asymmetric they also conclude that it does not differ for oil-exporting countries and oil-importing countries.

Other papers use a time-varying approach to examine the oil price-exchange rate relationship. Reboredo and Rivera-Castro (2013) reveals that crude oil prices had no effect on US dollar exchange rates and vice versa before the 2008 financial crisis. However, a negative oil price effect on the exchange rate became apparent from the onset of the 2008 crisis. This result is consistent with Reboredo (2012). Turhan et al (2014) showed that correlations between oil prices and the exchange rates of G20 countries were stronger during the 2003 Iraq invasion. During the 2008 financial crisis, correlations between oil prices and exchange rates also became stronger for all currencies in the G20 countries.

The pioneering work of Jones and Kaul (1996) considered the relationship between oil prices and stock markets. They used quarterly data over the post-war period of 1970 to 1991 to test the rational reaction of stock prices to oil price shocks using the dividend valuation model for the US, Canada, the UK and Japan. For all four countries, they showed that stock prices react to oil price shocks. They further demonstrate that US and Canadian stock markets rationally react to oil price shocks, whereas UK and Japanese stocks overreact to oil price shocks.

The literature following Jones and Kaul (1996) is inconclusive on how oil prices affect stock market prices. For example, Evangelia (2001), Papatetrou (2001), Filis (2010), Driesprong et al (2008), Al-rjoub and Am (2005), Lee and Zeng (2011), and Masih et al (2011) suggest that oil price movements have a significant negative effect on stock prices. While Apergies and Miller (2009) and Al-Fayoumi (2009) find the link between 
oil markets and stock markets to be very weak. In contrast, Basher and Sadorsky (2006) found a positive relationship between oil prices and 21 emerging stock market returns.

Some papers distinguish between oil price effects on the stock markets of net oilexporting countries and net oil-importing countries. Filis et al (2011) suggest that correlations between oil prices and stock market prices do not differ for oil-exporting countries and oil-importing countries. In contrast, Talukdar and Sunyaeva (2012) showed that oil price shocks have a negative effect on the real stock market returns of net oil-importing countries compared to positive effects for net oil-exporting countries. Conversely, Boldanov et al (2015) suggest that correlations between oil prices and stock markets are positive for oil-importing counties and negative for oilexporting countries during crises periods, such as wars in the Middle East. Wang et al (2013) noted that oil price shocks have a stronger explanatory power on the variability of stock returns in oil-exporting countries than oil-importing countries.

Filis et al (2011), Ciner et al (2013), Antonakakis and Filis (2013), Boldanov et al (2015) and Antonakakis et al (2017) examined the oil price-stock market relationship within time-varying frameworks and all conclude that this relation changes over time for a range of countries.

This review shows that the linkages between oil prices and exchange rates, and oil prices and stock markets have been examined extensively with varying conclusions. These different conclusions could be due to the use of different methodologies and types of data as well as national and regional characteristics. However, there has been no previous literature that examines crude oil price effects for small countries treating oil prices as exogenous. This study builds on the existing literature by examining the 
shock and volatility spill-over effects of international crude oil prices on Ghana's exchange rate and stock market using models that treat crude oil prices as, first, endogenous and, second, exogenous. The aim is to determine whether the crude oil price effect in Ghana is related to the treatment of the crude oil price. To the best of our knowledge, this will be the first examination of this issue for Ghana.

\section{Data}

This study uses data on Ghana's stock exchange composite index (GSECI), the US S\&P 500 index, the Ghanaian cedi exchange rate with the US dollar, and world Brent crude oil prices. The data are monthly over the period January 1991 to December 2015, yielding 300 observations. The period was chosen, first, because data was available for all the series during this period. Second, this period witnessed sharp movements in oil prices caused by both supply-led and demand-led factors such as conflicts in the Middle East, the actions of OPEC, and increases in global demand propelled by China's economic growth. Third, this period captures the global financial crisis of 2008 which led to the crash of stock markets.

The GSECI is a capitalization-weighted index that tracks the performance of all companies traded on Ghana's stock exchange (GSE). It is the only stock exchange in Ghana and the criteria for listings on the exchange include profitability, capital adequacy, years of existence, spread of shares, and management efficiency. In 2015 there were 37 listings and 2 corporate bonds on the GSE. The closing prices of listed equities are calculated using the volume weighted average price of each equity for every given trading day. The Ghana stock exchange introduced the GSECI in 2011 to replace the previous GSE All-Share index. This means two indices existed for the Ghana stock exchange at different times within our sample period; the GSE All-Share 
index covering the period from January 1991 to December 2010, and the GSECI covering the period from January 2011 to December 2015. The method of calculating the closing prices of shares since the GSECI was introduced is different from the method that was used during the regime of the GSE All-Share index. To link the two indices, we used a three-period moving average extrapolating method to forecast the GSE All-Share index one period ahead into January 2011. We then used this forecast value and the actual value of the GSECI for January 2011 to splice both indices into a single consistent series (details are available from the authors on request).

The S\&P 500 index is included in this study to capture the role of a global financial centre such as the US in transmitting macroeconomic news. All variables are defined in Table 1.

$<$ Table 1>

Figure 1 shows the growth rates (returns) of variables given by the first differences of the natural logarithms of the price series (variable names are prefixed with "DL"). All series exhibit volatility clustering typically associated with financial data. This suggests the use of a GARCH specification is appropriate. All four growth rate series fluctuate around broadly constant means that are, therefore, likely to be stationary. There are no obvious structural breaks although there are a few relatively minor (pulse) outliers. Hence, we do not consider modelling structural breaks. ${ }^{2}$

\footnotetext{
${ }^{2}$ Whilst the presence of structural breaks may seem likely due to the long time-span covered by our sample period we note that all our variables are specified as the growth rates that are obtained by applying the first difference to the natural logarithm of the levels data. If there are structural breaks in the form of shifts in the means of the levels data, these will be transformed into outliers after taking first differences. Hence, our use of first differenced data appears to have removed any such structural breaks that may have been present in the levels of the data. We also applied an econometric pre-test for potential structural breaks by estimating mean equation VARs that model structural breaks by including dummy variables
} 
$<$ Figure 1 >

Table 2 reports descriptive statistics of the return series. The mean monthly returns of all variables are positive. The Ghana stock exchange index has the highest mean return (0.0176), followed by the Ghana cedi exchange rate $(0.0157)$, while the crude oil price has the lowest mean return (0.0016). Domestic variables have higher mean returns than the global oil price and the S\&P 500. In terms of volatility, the coefficient of variation (denoted as CV) and the standard deviation (Std. Dev) suggest that the Ghana cedi exchange rate is the least volatile since it has the smallest CV (1.7134) and standard deviation (0.0269). On the other hand, the crude oil price is most volatile with the highest CV (53.6875) and standard deviation (0.0859).

$<$ Table 2>

According to the estimated skewness, the Ghana stock exchange index and (especially) the Ghana cedi exchange rate are positively skewed, indicating that large positive returns are more common than large negative returns. In contrast, the S\&P 500 and crude oil prices have negative skewness. Furthermore, all the return series are leptokurtic (kurtosis is greater than 3) indicating significantly fatter tails and higher peaks that tend to produce more outliers than the normal distribution. This is expected and is common with many financial return series. Finally, the Jarque-Bera statistics reject the normally distributed null for all series.

that allow the coefficients on all variables to change in three respective periods: $2000 \mathrm{~m} 01$, $2004 \mathrm{m01}$ and 2008m01. Based upon the Schwarz information criterion (SIC), the VAR model without breaks is preferred to the three VAR models that allow breaks. That is, the system SIC for the VAR without breaks is -12.732 which is lower than the corresponding statistic for the three models allowing parameter change, being: -12.559 (2000m01), -12.593 (2004m01) and $-12.612(2008 \mathrm{~m} 01)$. 
Table 2 also gives the Ljung-Box (1979) Q-statistics and corresponding p-values (in parentheses) for $12^{\text {th }}$ and $24^{\text {th }}$ order autocorrelation for both return series (LB-Q(12) and LB-Q(24)) and squared return series (LB-Qs(12) and LB-Qs(24)) following Li and Giles (2015). We strongly reject the no autocorrelation null for all return (except for the S\&P 500) and squared return series. Evident autocorrelation in the squared series indicates the existence of $\mathrm{ARCH}$ effects in all series. The ARCH LM test (proposed by Engle (1982)) for $1^{\text {st }}(\mathrm{ARCH} \operatorname{LM}(1)), 12^{\text {th }}(\mathrm{ARCH} \operatorname{LM}(12))$, and $24^{\text {th }}(\mathrm{ARCH} \operatorname{LM}(24))$ order $\mathrm{ARCH}$ effects confirms the presence of significant $\mathrm{ARCH}$ effects for all return series. Hence, the application of multivariate GARCH models (which we use) is appropriate.

We report the Augmented Dickey-Fuller (ADF) and Phillips-Perron (PP) tests for nonstationarity in Table 3. The results unambiguously indicate that all log-level series are I(1) - an "L" prefix indicates a variable in logarithmic form. Hence, it is appropriate to model the growth rates of these variables (as we do) because they are stationary. $<$ Table 3>

\section{Methodology}

As our aim is to examine the interdependence or spill-over effects across different variables and given the observed $\mathrm{ARCH}$ effects of the series, a multivariate $\mathrm{GARCH}$ model is appropriate. We therefore use variants of the standard multivariate GARCH BEKK model proposed by Engle and Kroner (1995) that is widely used in modelling volatility/shock spill-overs in simultaneous equations systems. The BEKK specification overcomes many of the problems associated with the $\mathrm{VECH}$ model that was first proposed by Bollerslev et al (1988), such as having fewer parameters to estimate and guaranteeing the positive semi-definiteness of the time-varying covariance matrices. 
We employ Kroner and Ng's (1998) extended the BEKK model that captures the asymmetries often exhibited by stock prices and other financial data. The mean equation employs a standard vector autoregressive (VAR) specification. The (conditional) variance-covariance (volatility) equation, $\boldsymbol{H}_{t}$, uses a BEKK $(1,1)$ form that allows for asymmetries, thus:

$\boldsymbol{H}_{t}=\boldsymbol{C}^{\prime} \boldsymbol{C}+\boldsymbol{A}^{\prime} \varepsilon_{t-1} \boldsymbol{\varepsilon}_{t-1}^{\prime} \boldsymbol{A}+\boldsymbol{G}^{\prime} \boldsymbol{H}_{t-1} \boldsymbol{G}+\boldsymbol{D}^{\prime} \boldsymbol{\epsilon}_{t-1} \boldsymbol{\epsilon}_{t-1}^{\prime} \boldsymbol{D}$

where $\boldsymbol{C}$ is an $(n \times n)$ lower triangular matrix of constants, while the $(n \times n)$ parameter matrices $\boldsymbol{A}, \boldsymbol{G}$ and $\boldsymbol{D}$ are:

$\boldsymbol{A}=\left[\begin{array}{llll}a_{11} & a_{12} & a_{13} & a_{14} \\ a_{21} & a_{22} & a_{23} & a_{24} \\ a_{31} & a_{32} & a_{33} & a_{34} \\ a_{41} & a_{42} & a_{43} & a_{44}\end{array}\right] ; \quad \boldsymbol{G}=\left[\begin{array}{llll}g_{11} & g_{12} & g_{13} & g_{14} \\ g_{21} & g_{22} & g_{23} & g_{24} \\ g_{31} & g_{32} & g_{33} & g_{34} \\ g_{41} & g_{42} & g_{43} & g_{44}\end{array}\right] ; \boldsymbol{D}=\left[\begin{array}{llll}d_{11} & d_{12} & d_{13} & d_{14} \\ d_{21} & d_{22} & d_{23} & d_{24} \\ d_{31} & d_{32} & d_{33} & d_{34} \\ d_{41} & d_{42} & d_{43} & d_{44}\end{array}\right]$

The variance-covariance matrix of shocks, $\varepsilon_{t-1} \varepsilon_{t-1}^{\prime}$, is given by:

$\boldsymbol{\varepsilon}_{t-1} \boldsymbol{\varepsilon}_{t-1}^{\prime}=\left[\begin{array}{cccc}\varepsilon_{1, t-1}^{2} & \varepsilon_{1, t-1} \varepsilon_{2, t-1} & \varepsilon_{1, t-1} \varepsilon_{3, t-1} & \varepsilon_{1, t-1} \varepsilon_{4, t-1} \\ \varepsilon_{2, t-1} \varepsilon_{1, t-1} & \varepsilon_{2, t-1}^{2} & \varepsilon_{2, t-1} \varepsilon_{3, t-1} & \varepsilon_{2, t-1} \varepsilon_{4, t-1} \\ \varepsilon_{3, t-1} \varepsilon_{1, t-1} & \varepsilon_{3, t-1} \varepsilon_{2, t-1} & \varepsilon_{3, t-1}^{2} & \varepsilon_{3, t-1} \varepsilon_{4, t-1} \\ \varepsilon_{4, t-1} \varepsilon_{1, t-1} & \varepsilon_{4, t-1} \varepsilon_{2, t-1} & \varepsilon_{4, t-1} \varepsilon_{3, t-1} & \varepsilon_{4, t-1}^{2}\end{array}\right]$

where $\epsilon_{t}$ is defined as $\varepsilon_{t}$ if $\varepsilon_{t}$ is negative and zero otherwise; while:

$\boldsymbol{\epsilon}_{t-1} \boldsymbol{\epsilon}_{t-1}^{\prime}=\left[\begin{array}{cccc}\epsilon_{1, t-1}^{2} & \epsilon_{1, t-1} \epsilon_{2, t-1} & \epsilon_{1, t-1} \epsilon_{3, t-1} & \epsilon_{1, t-1} \epsilon_{4, t-1} \\ \epsilon_{2, t-1} \epsilon_{1, t-1} & \epsilon_{2, t-1}^{2} & \epsilon_{2, t-1} \epsilon_{3, t-1} & \epsilon_{2, t-1} \epsilon_{4, t-1} \\ \epsilon_{3, t-1} \epsilon_{1, t-1} & \epsilon_{3, t-1} \epsilon_{2, t-1} & \epsilon_{3, t-1}^{2} & \epsilon_{3, t-1} \epsilon_{4, t-1} \\ \epsilon_{4, t-1} \epsilon_{1, t-1} & \epsilon_{4, t-1} \epsilon_{2, t-1} & \epsilon_{4, t-1} \epsilon_{3, t-1} & \epsilon_{4, t-1}^{2}\end{array}\right]$

We estimate the full BEKK model, equation (1), with all four-variables treated as endogenous, and a triangular BEKK (TBEKK) model where the crude oil price is treated as exogenous. The TBEKK model was also used by Beirne et al (2010) to examine volatility spill-overs from mature stock markets to regional and local emerging 
country stock markets. The TBEKK model uses the same formula as the full BEKK model, except the $\boldsymbol{A s}, \boldsymbol{G} \mathbf{s}$, and $\boldsymbol{D} \mathbf{s}$ are constrained to be lower triangular, thus:

$\boldsymbol{A}=\left[\begin{array}{cccc}a_{11} & 0 & 0 & 0 \\ a_{21} & a_{22} & 0 & 0 \\ a_{31} & a_{32} & a_{33} & 0 \\ a_{41} & a_{42} & a_{43} & a_{44}\end{array}\right] ; \quad \boldsymbol{G}=\left[\begin{array}{cccc}g_{11} & 0 & 0 & 0 \\ g_{21} & g_{22} & 0 & 0 \\ g_{31} & g_{32} & g_{33} & 0 \\ g_{41} & g_{42} & g_{43} & g_{44}\end{array}\right] ; \boldsymbol{D}=\left[\begin{array}{cccc}d_{11} & 0 & 0 & 0 \\ d_{21} & d_{22} & 0 & 0 \\ d_{31} & d_{32} & d_{33} & 0 \\ d_{41} & d_{42} & d_{43} & d_{44}\end{array}\right]$

In both BEKK and TBEKK systems above, the numbers 1, 2, 3, and 4 denote the growth rates of the Ghana stock market, the Ghana exchange rate, the US stock market, and world oil prices, respectively. For the TBEKK model these numberings/orderings are based on the relative degree of exogeneity of the variables. Assuming macroeconomic conditions in Ghana will unlikely influence crude oil prices, crude oil prices are allowed to affect the domestic variables (the Ghana exchange rate and the Ghana stock market) as well as the US stock market. However, the domestic variables are not allowed to affect the crude oil price. This makes crude oil prices exogenous. The ordering also allows the US stock market to affect the Ghana cedi exchange rate and the Ghana stock market, however neither domestic variable affects the US stock market because domestic variables will have little influence on the world stage.

From the systems above, we can analyse the variance or volatility across the variables. Matrix $\boldsymbol{A}$ measures past shock effects and matrix $\boldsymbol{G}$ measures past volatility effects. $^{3}$ The asymmetric responses to negative and positive shocks, or 'bad news'

\footnotetext{
3 Shocks are the errors (the difference between actual and fitted values, $\boldsymbol{\varepsilon}_{t}$ ) and volatilities the (conditional) variances $\left(\boldsymbol{H}_{t}\right)$. The coefficients on the lagged shocks are the ARCH coefficients, whilst the coefficients on the lagged variances/covariances are the GARCH coefficients. The ARCH and GARCH coefficients are used to describe shock spill-over and volatility spill-over respectively (e.g. see Li, 2007, Li and Giles, 2015, Musunuru, 2014, and Joshi, 2011).
} 
and 'good news', are measured by $\boldsymbol{D}$. The diagonal elements of matrix $\boldsymbol{A}\left(a_{i i}\right)$ measure the effects of market $i$ 's shocks on its own volatility, whilst the off-diagonal elements of $\boldsymbol{A}\left(a_{i j}\right)$ capture the effects of market $i$ 's shocks on market $j$ 's volatility ${ }^{4}$. Similarly, the diagonal elements of $\boldsymbol{G}\left(g_{i i}\right)$ measure the effects of the own past volatility of market $i$ on its conditional variance, whilst the off-diagonal elements of $\boldsymbol{G}\left(g_{i j}\right)$ capture the effects of past volatility of market $i$ on market $j$ 's conditional variance, also known as volatility spill-over. The diagonal elements of $\boldsymbol{D}\left(d_{i i}\right)$ are the asymmetric response of market $i$ to its own past shocks and measure the difference between positive shocks and negative shocks. The off-diagonal elements of $\boldsymbol{D}\left(\boldsymbol{d}_{\boldsymbol{i j}}\right)$ are the asymmetric responses of market $j$ to the past shocks of market $i$. They measure the difference between positive and negative shocks of market $i$ on market $j$ 's volatility. To measure the volatility spill-over effect of negative shocks, we take the sum of the coefficients of $a_{i j}$ and $d_{i j}\left(a_{i j}+d_{i j}\right)$. Similarly, for negative shocks of own volatility, we take the sum of $a_{i i}$ and $d_{i i}\left(a_{i i}+d_{i i}\right)$. Positive shocks are measured by $a_{i i}$ and $a_{i j}$. Note that all coefficients in the (T)BEKK specification are squared making negative coefficient signs irrelevant because they become positive once squared.

We use the standard $\operatorname{GARCH}(1,1)$ specification. Engle (1995, p.xii) noted that the GARCH(1,1) is a generally robust model whilst Bollerslev et al (1992) suggests that this model seems sufficient when modelling variance dynamics over very long sample periods. Further, increasing the lag order of the BEKK model may pose practical issues due to the large number of parameters. Our BEKK models are also deemed

\footnotetext{
${ }^{4}$ Because of the standard use of the transpose of $\boldsymbol{A}$ as the pre-multiplying matrix, the coefficients of the BEKK model have the opposite interpretation to usual: $\boldsymbol{A}(\mathrm{i}, \mathrm{j})$ is the effect of residual $\mathrm{i}$ on variable $\mathrm{j}$, rather than $\mathrm{j}$ on $\mathrm{i}$.
} 
valid since they all pass the autocorrelation and $\mathrm{ARCH}$ diagnostic tests (discussed below).

Following Engle and Kroner (1995) and Kroner and Ng (1998) our BEKK models are estimated consistently and efficiently using the full information maximum-likelihood method with the RATS 8.2 software. As recommended by Engle and Kroner (1995), we performed several iterations with the simplex algorithm. We then employed the BFGS (Broyden, Fletcher, Goldfarb, and Shanno) algorithm to obtain the final estimates. The next section discusses the empirical results.

\section{Results}

To test whether the models are adequately specified we apply the widely used LjungBox Q-statistic for unmodelled autocorrelation in the multivariate residuals and squared residuals ( $\mathrm{ARCH}$ effects) as well as the multivariate $\mathrm{ARCH}$ test. We report the Q-statistics for lag orders 12 (MVLB-Q(12)), 17 (MVLB-Q(17)), 24 (MVLB-Q(24)) and 36 (MVLB-Q(36)) based on previous literature (see Li, 2007, Joshi, 2011, Li and Giles, 2015 and Harvey, 1981). We also report a multivariate test for unmodelled $\mathrm{ARCH}$ effects of order $6(\mathrm{MVARCH}(6))$. The statistics and their p-values (in parentheses) for both mean and variance models are reported in the bottom sections of the tables of results. The diagnostic tests for all models suggest that the mean and variance specification are adequately specified as there is no significant autocorrelation or unmodeled $\mathrm{ARCH}$ effects according to the test statistics. Further, the estimation procedure converges for all models reported below suggesting no invalid estimation.

The models that treat world crude oil prices as endogenous are referred to as "endogenous crude oil price models" whilst those that treat world oil prices as 
exogenous are called "exogenous crude oil price models". We use a $5 \%$ level of significance for drawing inference in all models discussed below.

\subsection{Endogenous crude oil price model}

The results for the BEKK endogenous crude oil price model are reported in Table 4. The diagonal parameters in matrix $\boldsymbol{A}$ measure the effects of own past shocks on their conditional variance (ARCH effects). All the estimated diagonal parameters of matrix $\boldsymbol{A}\left(a_{11}, a_{22}, a_{33}\right.$ and $\left.a_{44}\right)$ are significant. The diagonal parameters in matrix $\boldsymbol{G}$ measure the effects of own past volatility on their conditional variance (GARCH effects). Except for $g_{11}$, all estimated parameters in the diagonal matrix $\boldsymbol{G}$ are significant. The significance of all the diagonal elements of matrices $\boldsymbol{A}$ and $\boldsymbol{G}$ (except $g_{11}$ ) indicates a strong $\mathrm{GARCH}(1,1)$ process driving the conditional variances of the four markets.

$<$ Table 4>

The diagonal elements of $\boldsymbol{D}$ measure the asymmetric response (the difference in response to good news and bad news) of the markets to their own past shocks. The estimated diagonal coefficients in $\boldsymbol{D}$ are not significant for $d_{11}$ and $d_{22}$ suggesting no significant asymmetries for the Ghana stock market and exchange rate. Meanwhile, the coefficients for $d_{33}$ and $d_{44}$ are significant indicating the presence of significant asymmetric effects for the US stock market and world oil prices. The results suggest that the own past negative effect of shocks for the US stock market $\left(a_{33}^{2}+d_{33}^{2}=\right.$ $0.3262)$ is larger in magnitude than its own past positive effect $\left(a_{33}^{2}=0.0821\right)$. Similarly, the own past negative effect of oil price shocks $\left(a_{44}^{2}+d_{44}^{2}=0.0421\right)$ is larger in magnitude than its own past positive effect $\left(a_{44}^{2}=0.0246\right)$. Thus, for both the US stock market and the world oil price, negative shocks have larger effects on their own conditional volatilities than positive shocks. 
We next discuss the off-diagonal parameters of $\boldsymbol{A}, \boldsymbol{G}$ and $\boldsymbol{D}$ which capture transmissions across markets. Starting with $\boldsymbol{A}$, which measures the overall shock spillovers among the variables, the significant coefficients of $a_{31}$ and $a_{32}$ indicate that there are shock spill-overs from the US stock market to the Ghanaian stock market, and from the US stock market to the Ghana cedi exchange rate. However, the reverse offdiagonal parameters $a_{13}$ and $a_{23}$ are not significant. This implies shocks to the Ghana stock market and the Ghanaian exchange rates have no spill-over effects on the US stock market. In other words, news about shocks of the US stock exchange affects the volatility of the Ghana stock exchange and the Ghana cedi exchange rate though not vice versa.

Moreover, we find evidence of bidirectional shock spill-over between the US stock market and oil prices as the parameters $a_{34}$ and $a_{43}$ are both significant. News about the US stock market affects the volatility of oil prices and vice versa. There are also shock spill-overs from the oil price to the Ghanaian exchange rate since $a_{42}$ is statistically significant. However, shocks to oil prices have no important spill-over effects on the Ghana stock market index since $a_{41}$ is insignificant.

With regards to volatility spill-over (indicated by the off-diagonal elements of $\boldsymbol{G}$ ), there is bidirectional volatility spill-over between international oil prices and the Ghana cedi exchange rate because $g_{42}$ and $g_{24}$ are both significant. The evidence that past volatility of the Ghana cedi exchange rate significantly affects the conditional variance of oil prices is unexpected. There is also a unidirectional volatility spill-over from oil prices to the US stock market because $g_{43}$ is significant while $g_{34}$ is not significant.

The spill-over effects of asymmetric shocks are indicated by the off-diagonal parameters of $\boldsymbol{D}$. There is evidence of asymmetric spill-overs between some of the 
variables. These include; asymmetric spill-overs from the Ghana exchange rate to the Ghana stock market; from oil prices to the US stock market; from the Ghana stock market to the US stock market; and from the Ghana cedi exchange rate to oil prices, since the parameters $d_{21}, d_{43}, d_{13}$, and $d_{24}$ are significant. However, there are no significant asymmetric effects from oil prices to the Ghana cedi exchange rate and the Ghanaian stock market.

Finally, the relationship between the return variables in the mean equation is captured by matrix $\boldsymbol{R} .{ }^{5}$ The results reveal that the returns of the Ghana stock market, the Ghana cedi exchange rate, and oil prices depend on their own previous values since $R_{11}, R_{22}$, and $R_{44}$ are significant. However, the coefficient of $R_{33}$ is statistically insignificant, indicating that the returns of the US stock market does not depend on its first lag. Further, return spill-overs (in the mean equation) between the variables appear to be non-existent since all the off-diagonal elements in $\boldsymbol{R}$ are insignificant.

Overall, the results from this model suggest that crude oil prices have significant shock, volatility, and asymmetric spill-over effects on the Ghana exchange rate. However, crude oil prices do not have any effect on the Ghana stock market. An issue with this model is that some of the results are surprising. For example, the results that the Ghana stock market has an asymmetric effect on the US stock market; and the Ghana currency has an asymmetric effect on the world oil price were not expected. Such unexpected results are prevented by construction in the exogenous crude oil price model considered next.

\footnotetext{
5 Where $\boldsymbol{R}=\left[\begin{array}{llll}R_{11} & R_{12} & R_{13} & R_{14} \\ R_{21} & R_{22} & R_{23} & R_{24} \\ R_{31} & R_{32} & R_{33} & R_{34} \\ R_{41} & R_{42} & R_{43} & R_{44}\end{array}\right]$ gives the coefficients of the VAR mean equation.
} 


\subsection{Exogenous crude oil price model}

The results for the TBEKK exogenous crude oil price model are reported in Table 5. The volatility of all the variables depend on their own past shocks as $a_{11}, a_{22}, a_{33}$, and $a_{44}$ are all significant indicating a strong $\mathrm{ARCH}$ process. The off-diagonal elements of $\boldsymbol{A}$ reveals that there are shock spill-overs from the US stock market to both the Ghana stock market and the Ghana cedi exchange rate since $a_{31}$ and $a_{32}$ are both significant. There are also shock spill-overs from the crude oil price to the Ghana cedi exchange rate. These results are consistent with the BEKK model results. With regards to volatility spill-overs, the parameters in $\boldsymbol{G}$ show that all the variables derive their own conditional variances from their own past volatility (except the Ghana stock market) as the diagonal elements $g_{22}, g_{33}$, and $g_{44}$ are all significant indicating strong GARCH effects. From the off-diagonal elements of $\boldsymbol{G}$, the Ghana cedi exchange rate and the US stock market both have significant volatility spill-over effects on the conditional variance of the Ghana stock market. The crude oil price also has significant volatility spill-over effects on the conditional variance of the Ghana cedi exchange rate. These results are similar to those from the BEKK model except that the volatilities of the Ghana cedi exchange rate and the US stock market have no effect on the Ghana stock market in the full BEKK model.

$<$ Table 5>

The significant diagonal parameters of $\boldsymbol{D}, d_{33}$ and $d_{44}$, indicate the presence of asymmetric responses of the US stock market and the crude oil price on their own past shocks. There are also significant cross-market asymmetric responses from the US stock market to the Ghana stock market and the Ghana cedi exchange rate. Asymmetric effects also spill-over from the crude oil price to the Ghana stock market 
and the Ghana exchange rate. For the asymmetries (see panel B), the effects of negative shocks are higher than positive shocks. These cross-market asymmetries were not found in the full BEKK model, and they represent differences in results from specifying crude oil prices as exogenous rather than endogenous.

In terms of return linkages in the mean equation, all variables depend on their previous values (except the US stock market) since $R_{11}, R_{22}$, and $R_{44}$ are significant. These results are consistent with the BEKK model. $R_{21}$ and $R_{31}$ are also significant indicating the existence of return spill-overs from the exchange rate to the Ghana stock market, and from US stock market to the Ghana stock market. This contrasts with the BEKK model where no cross-market return linkages were found. Hence, the existence of cross-market return linkages in the TBEKK model represents a difference in treating crude oil prices as exogenous rather than endogenous. Some results are robust across the two models whilst others are not which could reflect differences in the specification of crude oil prices as either endogenous or exogenous. Further, the unexpected results obtained when all variables were treated as endogenous (for example, the volatility spill-over effects from the Ghana currency to the world oil price, and the asymmetric shock spill-over from the Ghana stock market to the US stock market) are not found in the TBEKK model where crude oil prices are treated as exogenous (by construction/restriction). ${ }^{6}$

\footnotetext{
${ }^{6}$ As a robustness check (and for comparison) we also estimated a two-variable TBEKK model that omits stock markets from the four-variable TBEKK specification - the unreported results are available from the authors on request. In this model shocks from crude oil prices do not affect the volatility of the exchange rate while oil price volatilities affect the conditional variance of the exchange rate. The latter result is consistent with the four-variable TBEKK model, however, the former result is not. Another difference in results between the two models is that in the two-variable TBEKK model, crude oil prices have no asymmetric effects on the exchange rate, whereas this relationship is significant in the fourvariable TBEKK model. Here, we can argue that the interactions of the stock markets in the four-variable TBEKK model may play an important role in the asymmetric response between the crude oil prices and the Ghana cedi exchange rates.
} 
The results from the models above show that world crude oil price movements have some influence on the Ghana stock market and Ghana exchange rate. In some cases, the results depend on whether restrictions are imposed on the model. One conclusion is that the crude oil price effect on the exchange rate is not qualitatively different in the endogenous and exogenous crude oil price models. In both models, the world crude oil price has shock and volatility spill-over effects on the Ghana exchange rate. However, the crude oil price effect on the stock market is different. In the exogenous crude oil price model, oil price shocks have asymmetric effects on the Ghana stock market. However, no such effects are found in the endogenous crude oil price model.

Our preferred model treats crude oil prices as exogenous on a priori grounds. This is based on our assumption that economic activities in Ghana cannot influence world oil prices because of the relatively small size of the Ghanaian economy. The exogenous crude oil price model cannot provide implausible outcomes such as the Ghanaian exchange rate and the Ghana stock market affecting world crude oil prices, as found in the endogenous crude oil price model.

Our result that past shocks and volatility of world crude oil prices affect the volatility and conditional variance of the Ghana cedi exchange rate is not surprising. Achieving a higher growth rate has been the priority of the government of Ghana over the years. Hence, the monetary authorities often respond to rising oil prices by lowering interest rates to reduce the potential negative consequences of the oil price shocks on the economy. The consequent effect of declining interest rates is depreciation of the currency. For example, the 2003 oil shock led to a fall in interest rates from $24.5 \%$ in the previous year to $21.5 \%$ in 2003 . This resulted in a depreciation of the cedi exchange rate from 0.84 cedis per dollar in 2002 to 0.88 cedis per dollar in 2003. Also, the 2008 oil price shock compelled the government to lower interest rates, however, 
this did not happen until 2010. 2008 was an election year and, because inflation was already very high at $16.5 \%$, lowering interest rates could raise inflation further which could lead to a loss of public confidence in the government. Hence, the risk of public discontent, and its effects on the elections propelled the government to delay lowering interest rates until 2010. When interest rates were eventually lowered from $18 \%$ in 2009 to $13.5 \%$ in 2010 , the exchange rate depreciated from 1.41 cedis per dollar in 2009 to 1.47 cedis per dollar in 2010. The results can also be explained if we consider the demand for US dollars by Ghanaian importers of crude oil and petroleum products. Since oil contracts in the world market are denominated in US dollars, oil importers in Ghana need to sell the Ghanaian cedi to obtain US dollars. Therefore, as oil prices increase, more US dollars are bought, which means selling more cedis. This increase in demand for the US dollar raises its exchange rate at the expense of the Ghana cedi.

Our results relating to the oil price-exchange rate relationship are consistent with Gosh (2011), Lizardo and Mollick (2011), Amano and Norden (2008), Chen and Chen (2007), Beckmann and Czudaj (2013), Turhan (2014), Aziz and Abu Bakar (2011) and Benassy-Quere et al (2007). These papers also found evidence suggesting that oil price shocks have a significant effect on the exchange rates of various countries. However, the findings of Sari et al (2010), Reboredo (2012), and Reboredo and Rivera-Castro (2013) are inconsistent with our results as they found a relatively weak relationship between oil prices and a range of currencies.

The evidence from the exogenous crude oil price model suggests that the impact of oil price movements on the stock market in Ghana is weak in terms of shock and volatility spill-overs. However, there are asymmetric shocks from oil prices to the Ghana stock market, with significant negative shocks and zero positive shocks. Lin et al (2014) found significant asymmetric effects from oil prices to the Ghana stock 
market which is consistent with our findings. However, in contrast to our results they found significant shock and volatility spill-over effects from crude oil prices to the Ghana stock market. This difference in results could be attributed to various factors such as the type of data and methodologies used. For example, Lin et al (2014) used weekly data from 2000 to 2010 whilst our paper used monthly data running from 1991 to 2015 , which is a longer period. Also, whilst we employed four-variable BEKK models, Lin et al (2014) used bivariate VAR-GARCH, VAR-AGARCH, and DCCGARCH specifications. However, unlike Lin et al (2014), our models additionally include exchange rates and treat crude oil prices as exogenous. Hence, our results are likely to be superior to those of Lin et al (2014) given our longer sample, inclusion of exchange rates and our more plausible treatment of crude oil prices as exogenous.

\section{Conclusion}

This paper explored the dynamic interactions between world oil prices, the Ghana cedi exchange rate, the Ghana stock exchange index and the US stock market index using a set of GARCH-BEKK models. The GARCH-BEKK models estimate shock spill-over, volatility spill-over, and asymmetric shocks to determine whether these markets have causal relationships between them. Because of the relative size of the Ghana stock market and the Ghanaian economy in general, the Ghana stock market and the Ghana exchange rate are not expected to influence international crude oil prices. Hence, we more plausibly treat crude oil prices as exogenous in one model, which represents a contribution of our paper. However, we also consider a model where crude oil prices are treated as endogenous following the literature and to determine whether the treatment of crude oil prices affects the results. 
Our findings suggest that the crude oil price effect on the Ghana cedi exchange rate is unchanged regardless of whether crude oil prices are treated as exogenous or endogenous. In both models, we found significant shock, volatility, and asymmetric spill-over effects from crude oil prices to the Ghana cedi exchange rate. However, the crude oil price has an asymmetric effect on the Ghana stock market in the exogenous crude oil price model, whilst in the endogenous crude oil price model, the crude oil price has no significant effect of any kind on the Ghana stock market. Hence, the model that treats the crude oil price as exogenous yields results that are more consistent with theory than the models that treat the crude oil price as endogenous. We also prefer the exogenous crude oil price model on a priori grounds since the model restricts the effects of the Ghana stock market and the Ghana exchange rate on the world oil price and US stock market to be zero, which is consistent with theoretical expectations. The endogenous crude oil price model implausibly indicates some significance of Ghana's economy on world and US markets. Hence, our conclusions are based on the TBEKK model that treats oil prices as exogenous.

Our results have some important implications for policy makers and investors. The significant shock spill-over effect from oil prices to the Ghana exchange rate implies that oil prices have a role in exchange rate movements in Ghana. The government could use its interest rate policy to limit the effects of oil price shocks on the exchange rate. For example, the monetary authorities can raise interest rates to increase the demand for the local currency by foreign investors during oil price increases ${ }^{7}$. The

\footnotetext{
${ }^{7}$ The government has often prioritised economic growth at the expense of stabilizing prices and the exchange rate by lowering interest rates. However, given that the monetary authorities have struggled to stabilize the local currency for several years, the government could aim to achieve a balance between sustaining the growth rate and stabilizing the currency following oil price shocks. This is necessary because a persistent fall in the value of the local currency could result in the public's loss of confidence in the currency which could have significant consequences on the economy.
} 
government can also promote the use of alternative sources of energy such as solar or encourage the use of public transport systems and electric powered vehicles in order to limit the country's dependence on oil for energy. The capacity of the Tema Oil Refinery (the only oil refinery in Ghana) should also be expanded to allow the locally produced crude oil to be refined domestically. This will help reduce the country's dependence on imported oil. This result is also important for Ghanaian investors who hold diversified portfolios overseas. During turbulent times in the world oil market, internationally diversified portfolio investors in Ghana will need to evaluate their alternatives to protect their investments from exchange rate risk emanating from disturbances in the oil market (that often reflect world-wide political turmoil or fear in financial markets).

This study has some limitations. First, we used monthly data instead of the preferred daily series. This is because daily price series for Ghana for all four-variables during our sample period was not available. Future research could re-examine this topic when daily price series for longer periods become available. Second, because governments in most developing countries such as Ghana usually provide subsidies and regulate the prices of petroleum products, the effects of domestic oil prices and world crude oil prices on economic activities could be different. Hence, future research could examine the volatility spill-over effects of domestic oil prices on the Ghanaian exchange rate and the Ghana stock market. 


\section{Appendix: list of abbreviations}

ADF, Augmented Dickey-Fuller.

$\mathrm{ARCH}$, Autoregressive conditional heteroscedasticity.

BEKK, BEKK.

GARCH, Generalised autoregressive conditional heteroscedasticity.

GSE, Ghana's stock exchange.

GSECI, Ghana's stock exchange composite index.

LM, Lagrange Multiplier.

MVARCH, Multivariate Autoregressive conditional heteroscedasticity.

MVLB, Multivariate Ljung-Box.

OPEC, Organisation of the Petroleum Exporting Countries.

PP, Phillips-Perron.

TBEKK, Triangular BEKK.

UK, United Kingdom.

US, United States. 


\section{References}

Al-Fayoumi N A (2009) Oil Prices and Stock Market Returns in Oil-importing Countries: The Case of Turkey, Tunisia, and Jordan. European Journal of Economics, Finance, and Administrative Sciences, 16, 86-101

Alquist R. and Kilian L. (2010) What do we learn from the price of crude oil futures? Journal of Applied Econometrics, 25, 539-573

Amano R. A. and Norden V. S. (1998) Oil prices and the rise and fall of US real exchange rates. Journal of International Money and Finance, 17, 299-316

Antonakakis N. and Filis G. (2013) Oil Prices and Stock Market Correlation: A TimeVarying Approach. International Journal of Energy and Statistics, 1, 17-29

Antonakakis N., Chatziantoniou I., and Filis G. (2017) Oil shocks and stock markets: Dynamic connectedness under the prism of recent geopolitical and economic unrest. International Review of Financial Analysis, 50, 26

Apergis N. and Miller S. M. (2009) Do structural oil-market shocks affect stock prices? Energy Economics, 31, 569-575

Aziz M. I. A. and Bakar N. A. (2011): Oil Price and Exchange Rate: A Study between Net Oil-exporting and Net Oil-importing Countries. European Journal of Economics, Finance, and Administrative Sciences.

Bank of Ghana Statistical Bulletin (2015). [Online] Available at https://www.bog.gov.gh/privatecontent/Publications/Statistical Bulletin/2015/Statistic al\%20Bulletin\%20Sept\%202015\%20A4V1.1.pdf [Accessed 30 ${ }^{\text {th }}$ October 2018] 
Basher S. A. and Sadorsky P. (2006) Oil price risk and emerging stock markets. Global Finance Journal, 17, 244-251

Beckmann J. and Czudaj R. (2013) Oil prices and effective dollar exchange rates. International Review of Economics and Finance, 27, 621-636

Beirne J., Caporale G. M., Schulze-Ghattas M, and Spagnolo M. (2010) Global and regional spill-overs in emerging stock markets: A multivariate GARCH-in-mean analysis. Emerging Markets Review, 11, 250-260

Benassy-Quere A., Mignon V., and Penot A. (2007) China and the relationship between the oil price and the dollar. Energy Policy, 35, 5795-5805

Boldanov R. Degiannakis S. and Filis G. (2015) Time-varying correlations between oil and stock market volatilities: Evidence from oil-importing and oil-exporting countries. Munich Personal RePEc Archives, MPRA Paper No. 72082 [Online] Available at Online at https://mpra.ub.uni-muenchen.de/72082/ [Accessed $3^{\text {rd }}$ March 2017]

Bollerslev T., Engle R. F, and Wooldridge G. M. (1988) A Capital Asset Pricing Model with Time-varying Covariances. Journal of Political Economy, 96, 116-131

Bollerslev T., Chou R. Y., and Kroner K. F. (1992) ARCH modelling finance: a selective review of the theory and empirical evidence. Journal of Econometrics, 52, 5-59

Buyukashin B., Haigh M. S. and Robe M. A. (2010) Commodities and Equities: Ever a "Market of One"? Journal of Alternative Investments, 12, 76-95

Chen S. S. and Chen H. C. (2007) Oil prices and real exchange rates. Energy Economics, 29, 390-404 
Ciner C., Gurdgiev C., and Lucey B. M. (2013) Hedges and Safe Havens: An examination of stocks, bonds, gold, oil, and exchange rates, International Review of Financial Analysis, 29, 202-211

Dogan S., Ustaoglu M., and Demeza S. (2012) Relationship between Real Oil Price and Real Exchange Rate: the case of Turkey. Procedia-Social and Behavioral Sciences, 58, 1293-1300

Energy Commission of Ghana (2015) National Energy Statistics 2005 - 2014. [Online] Available at http://energycom.gov.gh/files/Energy\%20Statistics 2015.pdf [Accessed $11^{\text {th }}$ October 2017]

Engle R. F. (1995) ARCH: Selected Readings. Oxford University Press, New York

Engle R. F. and Kroner K. F. (1995) Multivariate Simultaneous Generalized ARCH. Econometric Theory, 11, 122-150

Filis G. (2010) Macro economy, stock market, and oil prices: Do meaningful relationships exist among their cyclical fluctuations? Energy Economics, 32, 877-886

Filis G., Degiannakis S., and Floros C. (2011) Dynamic correlation between stock market and oil prices: The case of oil-importing and oil-exporting countries. International Review of Financial Analysis, 20(3), 152-164

Ghanaweb (2007) The Re-denomination of the Cedi. [Online] Available at http://www.ghanaweb.com/GhanaHomePage/features/artikel.php?ID=116579 [Accessed 14 ${ }^{\text {th }}$ May 2013]

Ghosh S. (2011) Examining crude oil price-Exchange rate nexus for India during the period of extreme oil price volatility. Applied Energy, 88, 1886-1889 
Hamilton J. D. (1983) Oil and macro economy since World War 2. Journal of Political Economy, 91, 228-248

Hamilton J. D. and Wu J.C. (2004) Risk premier in crude oil futures prices. Journal of International Money and Finance, 42, 9-37

Harvey A. C. (1981) Time Series Models. Philip Allan, Oxford

Huang Y. and Guo F. (2007) The role of oil price shocks on China's real exchange rate. China Economic Review, 18, 403-416

iBrokergh (no date) About the Ghana Stock Exchange. [Online] Available at http://gh.ibrokerghana.com/index.php/market-information/ghana-stock-exchange [Accessed 14th May 2017]

Indexmundi (no date) Ghana Crude Oil Consumption by Year. [Online] Available at https://www.indexmundi.com/energy/?country=gh\&product=oil\&graph=consumption [Accessed 30th April 2018]

Jiang J. and Gu R. (2016) Asymmetrical long-run dependence between oil price and US dollar exchange rate - Based on structural oil shocks. Physica A, 456, 75-89

Joshi P. (2011) Return and Volatility Spill-overs among Asian Stock Markets. SAGE Open, 1-8

Kin S. and Courage M. (2014) The Impact of Oil prices on the Exchange Rate in South Africa. Journal of Economics, 5, 193-199

Kroner R. F. and Ng V. K. (1998) Modelling Asymmetric Comovements of Asset Returns. Review of Financial Studies, 11, 817-844 
Li H. (2007) International Linkages of the Chinese Stock Exchanges: A Multivariate GARCH Analysis. Applied Financial Economics, 17, 285-297

Li Y. and Giles D. (2015) Modelling Volatility Spill-over Effect between Developed Stock Markets and Asian Emerging Stock Markets. Journal of International Economics and Finance, 20, 155-177

Lin B., Wesseh P. K. and Appiah M. O. (2014) Oil price fluctuation, volatility spill-over, and the Ghanaian equity market: Implication for portfolio management and hedging effectiveness. Energy Economics, 42, 172-182

Lizardo R. A. and Mollick A. V. (2010) Oil price fluctuations and US dollar exchange rates. Energy Economics, 32, 399-408

Masih R., Peters S., and Mello L. D. (2011) Oil price volatility and stock price fluctuations in an emerging market: Evidence from South Korea. Energy Economics, 33, $975-986$

Muhtaseb B. M. A. and Al-Assaf G. (2017) Oil price fluctuations and their impact on stock market returns in Jordan: Evidence from an asymmetric cointegration analysis. International Journal of Financial Research, 8(1), 172-180

Munsunuru N. (2014) Modelling Price Volatility Linkages between Corn and Wheat: A Multivariate GARCH Estimation. International Advances in Economic Research, 20, $269-280$

Papapetrou E. (2001) Oil price shock, stock market, and economic activity in Greece. Energy Economics, 23, 511-532 
Reboredo J. C. (2012) Modelling oil price and exchange rate co-movements. Journal of Policy Modelling, 34, 419-440

Reboredo J. C., and Rivera-Castro M. A. (2013) A wavelet decomposition approach to crude oil price and exchange rate dependence. Economic Modelling, 32, 42-57

Sari R., Hammoudeh S., and Soytas U. (2010) Dynamics of oil price, precious metal prices, and exchange rate. Energy Economics, 32, 351-362

Selmi R., Bouoiyour J., and Ayachi F. (2012) Another look at the interaction between oil price uncertainty and exchange rate volatility: The case of small open economies. Procedia Economics and Finance, 1, 346-355

Talukdar K. H. and Sunyaeva A. (2012) Oil Price Shocks and Stock Market Returns: Evidence from 11 Members Countries of the OECD. The Clute Institute International Academic Conference, Las Vegas, Nevada, USA 2012

Turhan M. I., Sensoy A., and Hacihasanoglu E. (2014) A comparative analysis of the dynamic relationship between oil prices and exchange rates. Journal of International Financial Markets, Institutions, and Money, 32, 397-414

Wang Y., Wu C., and Yang L. (2013) Oil price shocks and stock market activities: Evidence from oil-importing and oil-exporting countries. Journal of Comparative Economics, 41(4), 1220-1239.

Yang L., Cai X. J., and Hamori S. (2017) Does the crude oil price influence the exchange rates of oil-importing and oil-exporting countries differently? A wavelet coherence analysis. International Review of Economics and Finance, 49, 536-547

Yousefi A. and Wirjanto T. S. (2004) The empirical role of the exchange rate on the crude-oil price formation. Energy Economics, 26, 783-799 
Zhang Y. J., Fan Y., Tsai H. T., and Wei Y. M. (2008) Spill-over effect of US dollar exchange rate on oil prices. Journal of Policy Modelling, 30, 973-991 
Figure 1: Price return graphs
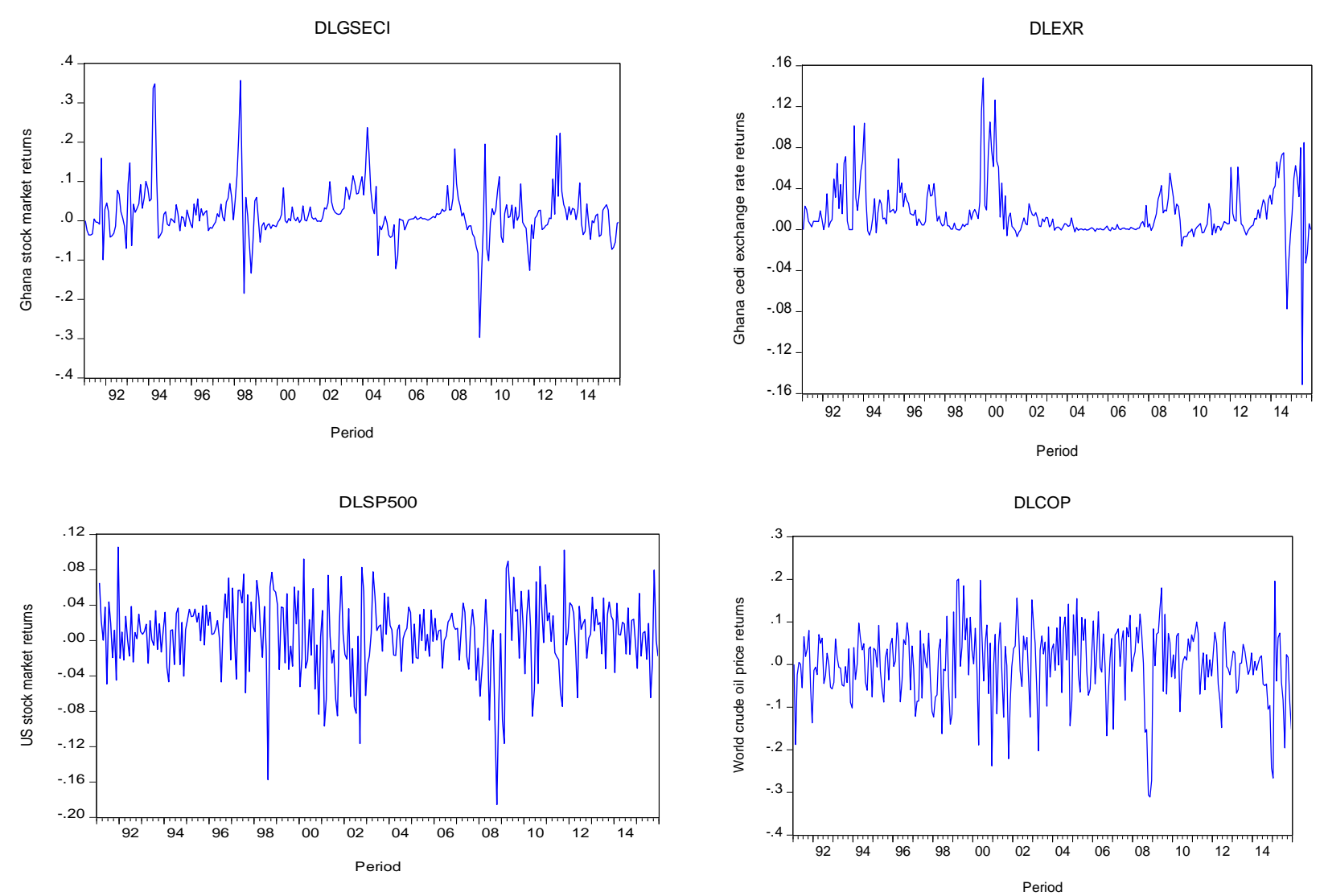
Table 1: Variable definitions and sources

\begin{tabular}{|l|l|l|}
\hline Variable & Description & Source \\
\hline GSECI & $\begin{array}{l}\text { Ghana stock exchange } \\
\text { index }\end{array}$ & $\begin{array}{l}\text { Ghana Stock Exchange } \\
\text { head office, Accra }\end{array}$ \\
\hline EXR & $\begin{array}{l}\text { Ghana cedi exchange rate } \\
\text { against the US dollar }\end{array}$ & $\begin{array}{l}\text { Oanda website } \\
\text { (www.oanda.com) }\end{array}$ \\
\hline SP500 & US stock market index & Yahoo Finance \\
\hline COP & $\begin{array}{l}\text { International Crude Oil } \\
\text { Price (UK Brent) }\end{array}$ & $\begin{array}{l}\text { Energy Information } \\
\text { Administration website }\end{array}$ \\
\hline
\end{tabular}

Table 2: Return series summary statistics

\begin{tabular}{|l|c|c|c|c|}
\hline & $\begin{array}{c}\text { Ghana Stock } \\
\text { Exchange }\end{array}$ & $\begin{array}{c}\text { Ghana Cedi } \\
\text { Exchange rate }\end{array}$ & SP500 & Crude Oil Price \\
\hline Mean & 0.0176 & 0.0157 & 0.0059 & 0.0016 \\
\hline Std. Dev & 0.0669 & 0.0269 & 0.0420 & 0.0859 \\
\hline CV & 3.8011 & 1.7134 & 7.1186 & 53.6875 \\
\hline Skewness & 1.1992 & 0.7040 & -0.8033 & -0.7082 \\
\hline Kurtosis & 10.485 & 11.493 & 4.8187 & 4.1993 \\
\hline Jarque-Bera & $772.15^{* * *}$ & $926.47^{* * *}$ & $73.36^{* * *}$ & $43.06^{* * *}$ \\
\hline LB-Q(12) & $(0.000)$ & $(0.000)$ & $(0.000)$ & $(0.000)$ \\
\hline & $115.23^{* * *}$ & $156.40^{* * *}$ & 11.07 & $30.77^{* * *}$ \\
LB-Q(24) & $(0.000)$ & $(0.000)$ & $(0.520)$ & $(0.000)$ \\
\hline & $153.69^{* * *}$ & $164.98^{* * *}$ & 17.70 & $44.92^{* *}$ \\
LB-Qs(12) & $(0.000)$ & $(0.000)$ & $(0.820)$ & $(0.010)$ \\
\hline & $54.52^{* * *}$ & $148.83^{* * *}$ & $55.01^{* * *}$ & $84.47^{* * *}$ \\
LB-Qs(24) & $(0.000)$ & $(0.000)$ & $(0.000)$ & $(0.000)$ \\
\hline & $63.06^{* * *}$ & $154.08^{* * *}$ & $72.97^{* * *}$ & $89.77^{* * *}$ \\
ARCH LM(1) & $(0.000)$ & $(0.000)$ & $(0.000)$ & $(0.000)$ \\
\hline & $38.46^{* * *}$ & $31.05^{* * *}$ & $17.93^{* * *}$ & $59.30^{* * *}$ \\
ARCH LM(12) & $(0.000)$ & $(0.000)$ & $(0.000)$ & $(0.000)$ \\
\hline & $38.20^{* * *}$ & $49.29^{* * *}$ & $35.32^{* * *}$ & $80.53^{* * *}$ \\
ARCH LM(24) & $(0.000)$ & $(0.000)$ & $(0.000)$ & $(0.000)$ \\
\hline
\end{tabular}

Note: LB-Q(12) and (24) denote the Ljung-Box Q-statistics for return series up to 12 and 24 lags whilst LB-Qs(12) and (24) represent the Ljung-Box Q-statistics for the squared return series. ARCH LM is the Lagrange multiplier test of autoregressive conditional heteroscedasticity for $\mathrm{ARCH}$ orders 1,12 , and 24. ${ }^{* * *},{ }^{* *}$, and ${ }^{*}$ denotes significance at the $1 \%, 5 \%$, and $10 \%$ levels respectively. 
Table 3: Unit root tests

Panel (a): ADF test statistics

\begin{tabular}{|c|c|c|c|c|c|c|c|c|}
\hline & \multicolumn{4}{|c|}{ Intercept only } & \multicolumn{3}{c|}{ Intercept and trend } \\
\hline & \multicolumn{2}{|c|}{ Levels data } & \multicolumn{2}{|c|}{ First differences } & \multicolumn{2}{c|}{ Levels data } & \multicolumn{2}{c|}{ First differences } \\
\hline & t-statistic & Lag & t-statistic & Lag & t-statistic & Lag & t-statistic & Lag \\
\hline LGSECI & -1.55 & 1 & $-10.05^{\star * \star}$ & 0 & -1.90 & 1 & $-10.11^{* * *}$ & 0 \\
\hline LEXR & -1.83 & 2 & $-7.38^{* *}$ & 1 & -1.77 & 2 & $-7.52^{\star * *}$ & 1 \\
\hline LSP500 & -1.69 & 0 & $-16.53^{* *}$ & 0 & -1.85 & 0 & $-16.53^{* * *}$ & 0 \\
\hline LCOP & -1.41 & 1 & $-14.11^{* *}$ & 0 & -1.77 & 1 & $-14.01^{* * *}$ & 0 \\
\hline
\end{tabular}

Panel (b): PP test statistics

\begin{tabular}{|c|c|c|c|c|}
\hline & \multicolumn{2}{|c|}{ Intercept only } & \multicolumn{2}{|c|}{ Intercept and trend } \\
\hline & Levels data & First differences & Levels data & First differences \\
\hline LGSECI & -1.45 & $-10.21^{\star \star *}$ & -1.87 & $-10.24^{\star \star \star}$ \\
\hline LEXR & -1.87 & $-12.43^{\star *}$ & -1.73 & $-12.55^{\star \star \star}$ \\
\hline LSP500 & -1.69 & $-16.61^{\star \star \star}$ & -2.00 & $-16.61^{* *}$ \\
\hline LCOP & -1.27 & $-14.11^{* \star *}$ & -2.00 & $-14.10^{\star \star \star}$ \\
\hline
\end{tabular}

Note: ${ }^{* * *},{ }^{* *}$, and ${ }^{*}$ denotes significance at the $1 \%, 5 \%$, and $10 \%$ levels respectively. 